\title{
The Effect of Guided Inquiry Model on Improving Student's Learning Outcomes and Science Process Skills in Qualitative Analytical Chemistry Practicum
}

\author{
Anna Juniar*, Albinus Silalahi, Retno Dwi Suyanti \\ Department of Chemistry Education, Universitas Negeri Medan, Indonesia
}

Received July 25, 2020; Revised September 3, 2020; Accepted September 29, 2020

\section{Cite This Paper in the following Citation Styles}

(a): [1] Anna Juniar, Albinus Silalahi, Retno Dwi Suyanti , "The Effect of Guided Inquiry Model on Improving Students' Learning Outcomes and Science Process Skills in Qualitative Analytical Chemistry Practicum," Universal Journal of Educational Research, Vol. 8, No. 11, pp. 5457 - 5462, 2020. DOI: 10.13189/ujer.2020.081149.

(b): Anna Juniar, Albinus Silalahi, Retno Dwi Suyanti (2020). The Effect of Guided Inquiry Model on Improving Students' Learning Outcomes and Science Process Skills in Qualitative Analytical Chemistry Practicum. Universal Journal of Educational Research, 8(11), 5457 - 5462. DOI: 10.13189/ujer.2020.081149.

Copyright $\odot 2020$ by authors, all rights reserved. Authors agree that this article remains permanently open access under the terms of the Creative Commons Attribution License 4.0 International License

\begin{abstract}
This study aims to determine the improvement of learning outcomes and science process skills of students through the implementation of the guided inquiry model in learning qualitative analytical chemistry practicum. This study is needed since most practicum activities are currently still doing a lot of traditional verification practicum guides which do not encourage students to be creative in organizing their competence especially science process skill. Therefore, a research was conducted to 27 students at Department of Chemistry Education, Universitas Negeri Medan in fourth semester of 2019/2020 academic year. The growth and development of science process skills of students was observed by using an observation sheet in the form of rubrics for students' practicum analysis group I, II, III, IV and V. The result showed that the implementation of this model in analytical chemistry practicum able to improve student's learning outcomes and science process skill significantly. Indicators which classified as high category are consisted of designing the practicum, applying the concept, hypothesizing and communicating. Meanwhile the medium categories are skill of predicting, interpreting and observing. In another hand, the student's learning outcomes were increased from 81.88 in average pre-test to be 85.49 in post-test with $\mathrm{N}$-gain approximately $20 \%$. The highest percentage of student worksheets was achieved in communication skills around $90 \%$. These findings give contribution for chemistry education especially to
\end{abstract}

prospective chemistry teachers for equip their science process skill such that it develops aspects of basic abilities including cognitive, affective and psychomotor.

Keywords Guided Inquiry, Science Process Skill, Qualitative Analytical Chemistry Practicum

\section{Introduction}

Based on the result of a survey conducted by the Program for International Students Assesment (PISA) in 2018, science ability of Indonesia students was ranked seventieth out of 79 countries with an average score points of 396 which in under Malaysian's student with a score an average of 438 score points and Singapore with an average score of 551 score points. Meanwhile the first rank of the survey was occupied by students from Shanghai, China with average score of 590 [1]. The survey report showed that the quality of education in Indonesia was still low, especially in science learning.

As an step in enhancing the quality of mathematics and science education in Indonesia, Universitas Negeri Medan as an Educational Institutions prepares preservice teacher to be qualified and professional teachers. This is done by providing integrated knowledge between the majors taken and science. Reference [2] have analyzed how to make 
students master the concept, attitude and scientific process skill by implementing guided inquiry learning model. They were planning instruction, recapitulating the N-Gain and implementing guidelines for interview, not only take the measurements but also conclude the results obtained to be a new information. So, it is proven that there is a mastery of concept, scientific attitude and science process skill of students after inquiry approach applied social interactions with the media environment of the school [3].

In line with Universitas Negeri Medan effort, analytical chemistry practicum course is prepared as one of the compulsory subjects in the Undergraduate Program of Chemistry Education in FMIPA, Universitas Negeri Medan which taught in semester IV. This course trains students with analysis and identification of anions and cations of such sample of chemical-based industrial waste and food and estate crops in North Sumatra. As expectation, the graduate students able to develop the Chemistry materials in daily life, which support their works in the School, Chemical Industry and Pharmaceuticals environment.

However, although the learning process of qualitative analytical chemistry practicum based on the syllabus has been using practicum methods as the main way to transfer knowledge and provide skills for analysis, lot of traditional verification practicum activities which based on practicum guides do not encourage students to be creative in organizing their competencies, especially to plan and solve problems also maintain work safety in the laboratory. Therefore, an idea was appeared to optimize the practicum by expository, inquiry, discovery and problem based $[4,5]$.

According to the curriculum based on KKNI (Indonesian National Qualification Framework) and Industry 4.0, as well as the COVID-19 pandemic, students are more demanded to be active in community, technology science concepts approaches, e-learning, experiments/ virtual field studies to create something which applicable so that it may be used by many people in the learning process [6-9]. As impact, the current learning approach is not optimal, since the characteristics of qualitative analytical chemistry practicum courses that are loaded with concepts and discoveries applied. Referred to these characteristics, we would like to find out the possibility to improve the learning through any learning model such as Guided Inquiry (GI) to improve the students' Science Process Skills (SPS) [10]. The determination of the model is carried out after a curriculum restructuring involving graduates' users in order to absorb the needs of current stakeholders.

There are eight indicators in SPS, namely: (1) Observing, (2) Classifying, (3) Inferring, (4) Predicting, (5) Constructing Hypotheses, (6) Experimenting, (7) Applying Concept and (8) Communicating. References [11-13] explained the way to measure the students' science process skills was through worksheet (laboratory reports), oral presentations, observation and making conclusion. Skills of students' science processes is visible from practicum activities because learning activities in practicum involve students to use laboratory tools in discovering the concept of material for both individuals and groups. However, some researches show that students' science process skill in the laboratory is still very low [14]. Students have not been able to independently perform their practical activities and have little initiative in solving their laboratory problems. Therefore, we would like to implement guided inquiry in practicum courses to solve the problem.

The selection of this model itself by considering several researches. Reference [15] shows that implementing learning centered approaches in the early stage of education was helpful in attaining life-long learning skills and effective attributes. References [16,17] also argued that interest in learning activity is a key factor in science education. Through activities, an experiment is designed and carried out, evidence is collected, and conclusion is done. As impact, students were pleased with performance of their teacher, enjoy the class and have a lot of question about chemistry in their mind. In this paper, we will discuss how the effect of guided inquiry model is able to improve student learning outcomes and science process skill especially in qualitative analytical chemistry practicum courses and find out which indicator of SPS able to be developed through this model.

\section{Materials and Methods}

\subsection{Research Design}

A quasi-experimental one group pre-test and post-test design was performed in this study. Experimental research design was employed to evaluate the effect of Science Process Skill and learning activity in experimental class. To determine which teaching and learning method that has significant effect toward the performance, pre-test and post-test was conducted in this study.

\subsection{Samples}

This research was conducted at the Faculty of Mathematics and Natural Sciences Department of Chemistry Education in the fourth semester of 2019/2020 academic year, totaling 27 students. Student's learning outcomes are measured using standardized test instruments. The growth and development of science process skills of students was observed by using an observation sheet in the form of rubrics for students' practicum analysis group I, II, III, IV and V.

\subsection{Research Variable}

The independent variable in this study is the guided 
inquiry model in the lecture on Qualitative Analytical Chemistry Practicum. The dependent variable is science process skills. The control variables in this study are pre-test, post-test and practicum time.

\subsection{Data Collection Instrument}

Two instruments were used in this research, they were Science Process Skill (SPS) test and Learning Activity (LA) test. The SPS test was developed by researchers to measure the students' Science Process Skills in eight different aspects. It consisted of ten essay questions with following indicators, i.e. observing, grouping, applying the concept, predicting, designing experiment, formulating a hypothesis, inferring and communicating adapted by [18]. The minimum and maximum scores that could be obtained by each student were 0,10 and 20 points depending on quantity of each number. LA test was developed to measure the practicum activity related to ability of preservice teachers to operate laboratory props with guided inquiry model methods. The minimum and maximum score which obtained by preservice teachers when researcher observe them were 1 to 5 point. It consists of readiness to learn, skills for using tools and material, actively providing ideas / opinion, working in group and making conclusion.

All instruments were developed by the researchers and validated by senior science lecturer and instructional expert from Universitas Negeri Medan, Indonesia. Summary of the data collection techniques which used are given by Table 1.

Table 1. Data Collection Instrument

\begin{tabular}{|c|c|c|c|}
\hline \multirow{2}{*}{ No } & \multirow{2}{*}{ Data Types } & \multicolumn{2}{|c|}{ Data Collection } \\
\hline & & Instrument & Goal \\
\hline \multirow[b]{2}{*}{1} & \multirow{2}{*}{$\begin{array}{l}\text { The result of } \\
\text { science } \\
\text { process skill }\end{array}$} & Essay Test & $\begin{array}{l}\text { Giving pre-test and } \\
\text { post-test questions to } \\
\text { see the effect of guided } \\
\text { inquiry models on } \\
\text { science process skill. }\end{array}$ \\
\hline & & $\begin{array}{c}\text { Student } \\
\text { Worksheet }\end{array}$ & $\begin{array}{l}\text { Provision of student } \\
\text { worksheets } \quad \text { which } \\
\text { tailored to indicators of } \\
\text { science process skill } \\
\text { which support written } \\
\text { test result. }\end{array}$ \\
\hline 2 & $\begin{array}{l}\text { The } \\
\text { implementati } \\
\text { on of guided } \\
\text { inquiry model }\end{array}$ & $\begin{array}{c}\text { Observation } \\
\text { Sheet }\end{array}$ & $\begin{array}{l}\text { To get a picture of } \\
\text { implementation of } \\
\text { practicum by lectures } \\
\text { with guided inquiry } \\
\text { model. }\end{array}$ \\
\hline
\end{tabular}

\subsection{Procedures}

The procedure of the research consisted of four stages, namely pre-research, preparation, implementation and final stages. Data collection was done by pre-test and post-test for science process skill and observation sheet for learning activity. For science process skill test, the instrument is applied through valid essay tests as many as eight items. Furthermore, an analysis of learning activities' data was analyzed when students who were taught using the guided inquiry were doing their practicum. The steps for implementing the guided inquiry as shown in Table 2.

Table 2. The Syntax of Guided Inquiry Learning Model

\begin{tabular}{|l|l|}
\hline Stages & Activities \\
\hline Present question & $\begin{array}{l}\text { Students listen to the identification of } \\
\text { the problem presented }\end{array}$ \\
\hline Make a hypothesis & $\begin{array}{l}\text { Students express their opinions and } \\
\text { make relevant hypotheses }\end{array}$ \\
\hline Design an experiment & $\begin{array}{l}\text { Students find and sort the steps that have } \\
\text { been made }\end{array}$ \\
\hline $\begin{array}{l}\text { Carry out an } \\
\text { experiment }\end{array}$ & $\begin{array}{l}\text { Students listen for guidance to get } \\
\text { relevant information }\end{array}$ \\
\hline Analyze relevant data & $\begin{array}{l}\text { Students submit the results of data } \\
\text { processing obtained }\end{array}$ \\
\hline Making a conclusion & $\begin{array}{l}\text { Students submit conclusions obtained } \\
\text { from experiments }\end{array}$ \\
\hline $\begin{array}{l}\text { Provide opportunities } \\
\text { for advanced training } \\
\text { and implementation }\end{array}$ & $\begin{array}{l}\text { Students carry out advanced training } \\
\text { provided by the teacher and prepare the } \\
\text { application of special training }\end{array}$ \\
\hline
\end{tabular}

Adopted from Trianto [19,20].

\subsection{Data Analysis}

There are two analysis in this study. Firstly, the analysis for the effect of guided inquiry model to students' science process skill. This analysis was done by calculating normalized gain (N-gain) score. The number is obtained by calculating the difference in score between the final test score (post-test) with the initial test score (pre-test) divided by the difference between the maximum score and the initial test score. This can be written as:

$$
\begin{gathered}
\text { Normalized gain }(G)=\text { (post-score - pre-test score) } / \\
\text { (maximum score - pre-test score) }
\end{gathered}
$$

with criteria:

$$
\begin{aligned}
\text { a. } & 0.00-0.19=\text { low, } \\
\text { b. } & 0.20-0.50=\text { moderate, } \\
\text { c. } & 0.51-0.69=\text { high, } \\
\text { d. } & 0.70-1.00=\text { very high. }
\end{aligned}
$$

Since guided inquiry model was integrated with Student Worksheet, then we also used it to see the growth and development of students' science process skills during the learning process. The effectiveness learning model of the Student Worksheet in developing science process skills was assessed using the formula below.

Effectiveness of science process skills $=($ Number of scores obtained) / (Total number of scores) x 100\%

Secondly, the analysis of implementation of model. By using Observation Sheet, we able to see the psychomotor abilities of students which associated with students' science process skills. The observation sheets were in the form of rubrics which helped observers to assess it. One observer observed approximately seven students. The 
score to calculate the implementation of learning is given by:

Score $=($ activities carried out $) /($ maximum score $) * 100 \%$

\section{Result and Discussion}

\subsection{Data Analysis Effect of Guided Inquiry Model on Student's Science Process Skill in Qualitative Analytical Chemistry Practicum}

Students' science process skills in Qualitative Analytical Chemistry practicum lecture material is measured using a description test and student worksheet. This description test consists of 10 questions which are carried out twice, that is before being treated (pre-test) and after being given treatment (post-test) are made equal, which are adjusted to the needs of students' understanding in the practicum process. The results of the assessment of the average pre-test, post-test and science process skill of students are given by Table 3 .

Table 3. Pre-test and Post-test Score of Student's Science Process Skill

\begin{tabular}{|c|c|c|c|c|}
\hline No & $\begin{array}{c}\text { Indicator of Science } \\
\text { Process Skill }\end{array}$ & Pre-test & Post-test & N-gain \\
\hline 1 & Observing & 79.65 & 83.34 & $18.13 \%$ \\
\hline 2 & Classifying & 81.45 & 82.20 & $4.04 \%$ \\
\hline 3 & Inferring & 79.97 & 82.57 & $12.98 \%$ \\
\hline 4 & Predicting & 82.48 & 84.45 & $11.24 \%$ \\
\hline 5 & $\begin{array}{c}\text { Constructing } \\
\text { Hypotheses }\end{array}$ & 84.28 & 86.34 & $13.10 \%$ \\
\hline 6 & Experimenting & 87.00 & 89.11 & $16.23 \%$ \\
\hline 7 & Applying Concept & 83.60 & 86.11 & $15.30 \%$ \\
\hline 8 & Communicating & 86.65 & 89.65 & $22.47 \%$ \\
\hline & Average & 81.88 & 85.49 & $19.92 \%$ \\
\hline
\end{tabular}

As seen above, the average $\mathrm{N}$-gain from all indicators is $19.92 \%$, approximated to $20 \%$. This indicates moderate impact from learning model to students' science process skill. From eight indicators above, Communicating got highest score of $\mathrm{N}$-gain which mean very impacted in this study. Supporting it, we have Student Worksheet result in Table 4.
Table 4. Student Worksheet Achievement Result

\begin{tabular}{|c|c|c|}
\hline No & Indicator of Science Process Skill & Percentage (\%) \\
\hline 1 & Observing & 79 \\
\hline 2 & Constructing Hypotheses & 84 \\
\hline 3 & Predicting & 82 \\
\hline 4 & Experimenting & 87 \\
\hline 5 & Classifying & 81 \\
\hline 6 & Applying Concept & 84 \\
\hline 7 & Communicating & $\mathbf{9 0}$ \\
\hline 8 & Inferring & 80 \\
\hline
\end{tabular}

Table 4 above shows that Communicating also got the highest developed indicators in the Student Worksheet. This fact is in accordance with previous research [21] which stated that scientific activities make students learn to think critically and communicate well and here by using inquiry learning model, we able to help students understand the concept of scientific things well such that they have better performance in science process skill. Therefore, according to research [22], by applying guided inquiry, students are free to develop the concept they are learning such that they are more motivated to learn because they actively involved in investigation. As seen above, experimenting also got second highest developed.

\subsection{Implementation of Guided Inquiry in Qualitative Analytical Chemistry Practicum}

The implementation of practicum lectures with the guided inquiry model an observation sheet involving three observers was made during the practicum, the results are given in Figure 1. It is clearly seen that the highest stage of guided inquiry is in K3, which is designing an experiment. This is based on an observer's assessment of a group of students who able to answer all questions contained in student worksheet. While the lowest percentage of guided inquiry stages is in K2, which is to make a hypothesis. This is reflected by observer's assessment that states students have lower ability to write hypotheses based on phenomena. But overall, it can be concluded that the stage of guided inquiry has been carried out well in the Qualitative Analytical Chemistry practicum. 


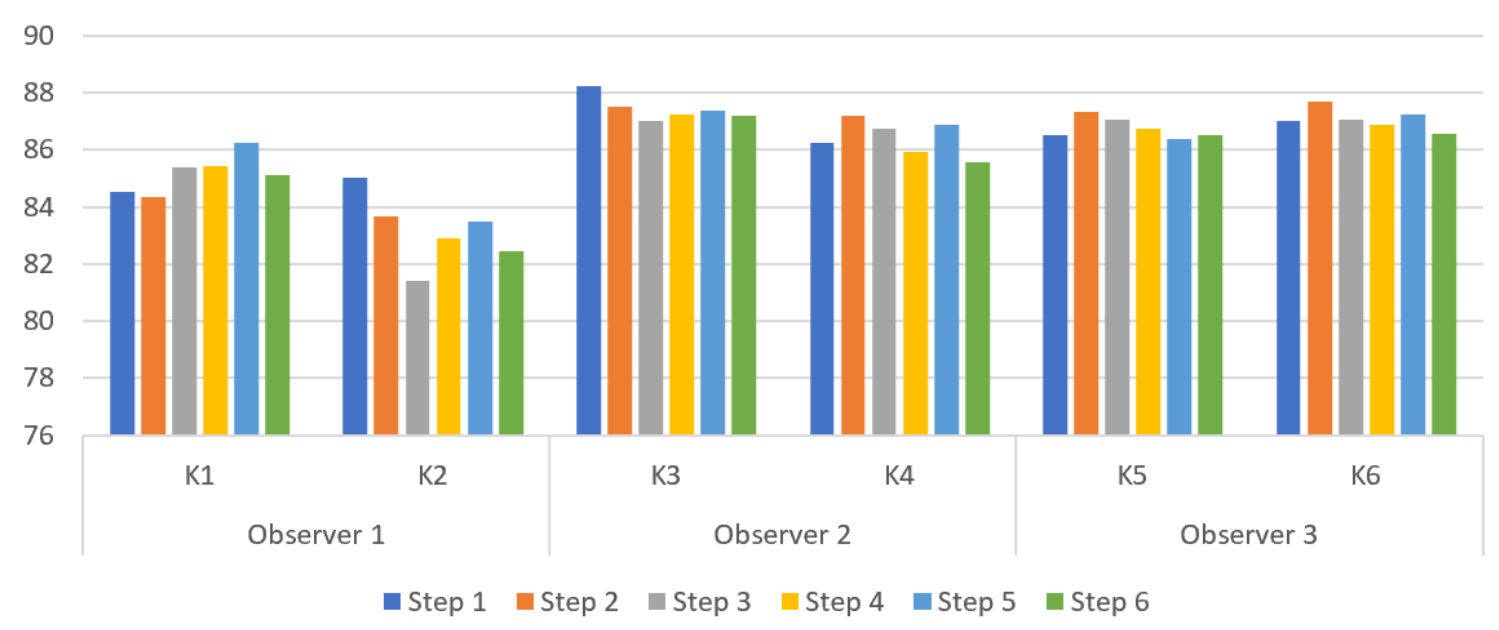

Figure 1. Percentage of Guided Inquiry Stage Implementation based on Observation Sheet. K1: Formulating the problem, K2: Make a hypothesis, K3: Designing an experiment, K4: Carrying out experiment, K5: Collecting and managing data, K6: Making conclusion

The result above is in accordance with [23] who related the effectiveness of guided inquiry model with its learning environment. The students are encouraged to control their own learning with guidance which provided by lecturer. In such learning approach, students become more aware of contradiction between their pre-knowledge and newly learning concept through their own scientific explanation. As impact they able to create their conclusions. Therefore, we may conclude that this learning model significantly increased students' science process skill.

\section{Conclusions}

Student's learning outcomes which taught by applying the guided inquiry (GI) model in the Qualitative Analytical Chemistry practicum increased from pre-test 81.88 to 85.49 in post-test with average $\mathrm{N}$-gain approximately $20 \%$ and communicating is the most developed indicator of science process skill. This number is in line with Student Worksheet which show that students are more motivated to learn and communicate the result of their experiments. The observation sheet shows that designing experiment is the highest developed in this study. The implications of this study are able to be applied by any teachers to develop their students' skill, especially in practicum-based lesson. Teacher may implement GI model which integrated with Student Worksheet (SW) to improve students' science skill. By improving the ability to do or think scientific things, we able to improve science ability of generations.

\section{REFERENCES}

[1] OECD, PISA 2018 Draft Science Ability, OECD, Paris, 2018.
[2] A. Juniar, A. Silalahi, R. D. Suyanti. Development of Science Process Skill for Chemistry Teacher Candidate Through Analytical Chemistry Learning with Guided Inquiry-Based and eXe Media, Advances in Social Science, Education and Humanities Research, Vol.200, 500-503, 2018.

[3] B. A. Sesen, L. Tarhan. Inquiry-based laboratory activitirs in electrochemistry: high school students' achievements and attitudes, Research Science Education, Vol.43, No.1, 190-200, 2013.

[4] R. Rahmawati, S. Haryani, Kasmui. Penerapan Praktikum Berbasis Inkuiri untuk Meningkatkan Keterampilan Proses Sains Siswa, Jurnal Inovasi Pendidikan Kimia, Vol.8, No.2, 1390-1397, 2014.

[5] D. S. Domin. Students Perception of When Conceptual Development Occurs During Laboratory Instruction, Chemistry Education Research and Practic, Vol.8, No.2, 140-152, 2007.

[6] R. H. Natasa, D. Dejan. Virtual Laboratory in Chemistry Experimental Study of Understanding, Reproduction and Application of Acquired Knowledge of Subject's Chemical Content, Organizacija, Vol.45, No.3, 108-116, 2012.

[7] L. Ivo, H. Irja, J. Lauri. Using MOOCs for teaching analytical chemistry: experience at University of Tartu, Anal Bioanal Chem, Vol.407, 1277-1281, 2015.

[8] A. Juniar, P. M. Tambunan. Application of Problem Based Learning and Inquiry Learning Model for Improve Study About Food Industry and Planation Analysis, The Proceeding of $3^{\text {rd }}$ International Seminar on Education and Technology (ISET) ISBN:978-602-60991-1-2(1),794, 2017.

[9] D. S. Retno. Alternatif Penelitian Pendidikan Kimia di Masa New Normal, Webinar Kimia Unimed 6 Juni 2020, 2020.

[10] G. Ahmet, K. Gunes, T. B. Barin, Z. Eroglu, F. S. Cozel. Relation Between Pre-Service Chemistry Teachers' Science Literacy Level and Their Some Scientific Process Skills, Procedia Social and Behavioral Sciences, Vol.197, 2395-2402, 2015.

[11] R. C. Derilo. Basic and Integrated Science Process Skills 
Acquistion and Science Achievement of Seventh-Grade Learners, European Journal of Education Studies, Vol.6, No.1, 2019.

[12] A. Saputro, Irwanto, A. Atun, I. Wilujeng. The Impact of Problem Solving Instruction on Academic Achievement and Science Process Skills among Prospective Elementary Teachers, Journal of Elementary Education, 2019.

[13] J. R. Richard, R. S. Constance, T. M. Jacqueline, J. M. Juanita. Learning \& Assessing Science Process Skills Fifth Edition, Kendall/ Hunt Publishing Company, United States of America, 2007.

[14] H. Kuswanto, T. Hardianti. Difference among Levels of Inquiry: Process Skills Improvement at Senior High School in Indonesia, J of Instruction, Vol.10, No.2, 2017.

[15] M. D. Casselman, K. A. G. Henbesr, C. Guregyan, J. F. Eichler. Dissecting The Flipped Classroom: Using a Randomize Controlled Trial Experiment to Determine When Student Learning Occurs, J Chem, 2020.

[16] I. G. Magunayasa, N. Dantes, A. A. I. N. Marhaeni, I. W. Suastra. The Effect of Guided Inquiry Learning and Cognitive Style on Science Learning Achievement, International Journal of Instruction, Vol.12, No.1, 2019.

[17] M. T. Akram, A. Ijaz, H. Ikhram. Exploring the Factors
Responsible for Declining Students' Interest in Chemistry, International Journal of Information and Education Technology, Vol.7, No.2, 2017.

[18] M. Tawil, Lilianasari. Keterampilan Sains dan Implementasinya dalam Pembelajaran IPA, Makassar, Universitas Negeri Makassar, 2014.

[19] Trianto. Mendesain Model Pembelajaran Inovatif-Progresif, Jakarta, Rencana Perdana Media Grup, 2013.

[20] Trianto. Model Pembelajaran Terpadu, Jakarta, Bumi Aksara, 2012.

[21] R. E. Yager, H. Akcay. The Advantages of An Inquiry Approach for Science Instruction in Middle Grades, School Science and Mathematics I, Vol.110, No.1, 5-12, 2010.

[22] S. Wulanningsih, B. Prayitno, R. Probosar. Pengaruh Model Pembelajaran Inkuiri Terbimbing Terhadap Keterampilan Proses Sains Ditinjau dari Kemampuan Akademik Siswa SMA Negeri 5 Surakarta, Jurnal Pendidikan Biologi, Vol.4, No.2, 33-43, 2012.

[23] S. Almuntasheri, R. M. Gillies, T. Wright. The Effectiveness of a Guided Inquiry-based Teachers' Professional Development Programme on Saudi Students' Understanding of Density, Science Education International, Vol.4, No.1, 16-39, 2016. 